\title{
The Sports Industry And Collective Bargaining
}

\section{Paul D Staudohar New York State School of Industrial and Labor Relations}

Rethinking Sports Labor Negotiations Avoiding the Next Sports. ILR Press, New York State School of Industrial and Labor Relations, Cornell University, 1986 - Sports \& Recreation - 195 pages. The Sports Industry and Collective Bargaining: Paul D. Staudohar Much More Than a Game: Players, Owners, and American Baseball. - Google Books Result Introduction to iCollective Bargaining in American Industry. 2 Mar 2005. As a result, the professional sports industry finds refuge under public.. the benefits arising from the labor laws and collective bargaining, but Sports Law in South Africa - Google Books Result Paul D. Staudohar, The Sports Industry and Collective Bargaining. ILR. Press, Ithace, 1986. pp.viii+195. In early 1986, Berry, Gould and Staudohar published a BERA: Issue 3/4 The Sports Industry: Basketball - Library of Congress The sports industry and collective bargaining Paul. - Google Books Introduction to Collective Bargaining in American Industry: Contemporary. is highly centralized professional sports in others it takes place entirely at. 1 Sep 2015. Labor Relations and the Sports Industry: Collective Bargaining in The union contract, called the Collective Bargaining Agreement CBA, can The Role of Antitrust Laws in the Professional Sports Industry From a. Covington \& Burling LLP Industries Sports The Sports Industry and Collective Bargaining. Front Cover. Paul D. Staudohar. ILR Press, New York State School of Industrial and Labor Relations, Cornell Collective Bargaining - BusinessDictionary.com The professional team sports industry is not exempt. The monetary Sports: A. Perspective On Collective Bargaining in the NFL, 1989 DuKE L.J. 328, 335. WEBINAR: The Sports Industry: A Business of Nuance However, in a large array of sports and entertainment industries, unions are robust. examines the intersection of these areas in collective bargaining in sports Step Up to the Scale: Wages and Unions in the Sports Industry University of Colorado,. Boulder. Paul D. Staudohar, The Sports Industry and Col lective Bargaining Ithaca, NY: ILR Press 1986. This is one of the few books. Collective Bargaining and the Professional Team Sport Industry Learn about the business side of sport management and explore concepts and theories unique to the industry. Topics range from collective bargaining and labor The Protestant Ethic and the Spirit of Sport: How Calvinism and. - Google Books Result The salary cap in effect under the 1999 collective bargaining agreement has provided owners some predictability with expenses. And revenue from local and ?The Sports Business as a Labor Market Laboratory sional sports leagues have experienced major changes in labor market rules and. The MLBPA achieved a collective bargaining agreement in 1968, and in Collective Bargaining in the Private Sector - Google Books Result The Sports Industry and Collective Bargaining Paul D. Staudohar on Amazon.com. *FREE* shipping on qualifying offers. Book by Staudohar, Paul D. The Sports Industry and Collective Bargaining by Paul D. - jstor Buy The sports industry and collective bargaining by Paul D Staudohar ISBN: 9780875461175 from Amazon's Book Store. Free UK delivery on eligible orders. Antitrust Labor Law Issues in Sports - Sports Law 29 Feb 2000. The Sports Industry and Collective Bargaining Labor Negotiations - Recreation \& Entertainment Industries - General \& Miscellaneous - Sports Leroy: Collective Bargaining in Sports and Entertainment ? Professional sports leagues make up a world of their own in which the best. factory, plant, firm, or industry developed through collective bargaining and. Catalog Record: The sports industry and collective bargaining. 22 Mar 1971. professional team sport industry.4 This creep has, in fact, reached the -currently represent most players in collective bargaining with the The Sports Industry and Collective Bargaining by Paul D. Staudohar In the sports industry, the unions that represent the players are called players. in 1932 and allows employees to organize as a collective bargaining units. Sport Management Graduate Certificate? SNHU The sports industry and collective bargaining: Amazon.co.uk: Paul D Covington's dedication to the business of sports runs broad and deep. NFL's recently ratified Collective Bargaining Agreement as well as to the dismissal of an The Sports Industry and Collective Bargaining: Paul D. - Amazon.ca The sports industry and collective bargaining / Paul D. Staudohar. Published: Ithaca, N.Y.: ILR Press, New York State School of Industrial and Labor Relations Labor Relations in the National Hockey League - Marquette Law. 3 Feb 2015. differences between professional sports leagues and teams and other industries in business practices from collective bargaining, motivation, The Sports Industry and Collective Bargaining - Paul. - Google Books The Sports Industry and Collective Bargaining: Paul D. Staudohar: 9780875461519: Books - Amazon.ca. Paul D. Staudohar, The Sports Industry and Collective Bargaining The sports industry and collective bargaining / Paul D. Staudohar Labor unions often loom large in the media, especially in the auto, airline and sports industries. Their methods of collective bargaining are often so effective that Collective Bargaining in Professional Sports - Labor Relations and. 26 Jul 2011. Indeed, professional sports are less like the automobile industry and more For starters, the collective bargaining agreement, which currently The Business of Professional Sports - Google Books Result Available in the National Library of Australia collection. Author: Staudohar, Paul D Format: Book vi, 217 p. 23 cm. 